\title{
PENYULUHAN BAHAN TAMBAHAN MAKANAN UNTUK SISWA SEKOLAH DASAR SANTA MARIA 2 PEKANBARU
}

http:/jumal.stk:ppersada.ac:id/jumal/index:php/JPM E-ISSN 2580-5300

\author{
Karolina Rosmiati \\ Prodi D III Analis Kesehatan, Akademi Kesehatan John Paul II Pekanbaru \\ Email: karolina.rosmiati.akjp2.ac.id.
}

\begin{abstract}
According to the Food Agriculture Organization (FAO), BTP is a compound that is intentionally added to food in certain quantities and sizes and is involved in the processing, packaging, or storage process. This material serves to improve color, shape, taste, and texture, and to extend shelf life, and is not the main ingredient. Ironically, many traders use dangerous BTP such as formaldehyde, borax, dyes and bleach which can actually harm human health Children are one of the targets of dangerous foods that are deliberately produced by certain individuals because they lack knowledge of the types of food additives. . The purpose of this activity is to introduce food additives to children from an early age so that in the future they will pay attention and be selective in consuming certain types of food. The method used is educational in nature and is accompanied by a demonstration of testing for hazardous substances in food.
\end{abstract}

Keyword: ingredients, additives, food, students

\begin{abstract}
Abstrak : Menurut Food Agriculture Organization (FAO), BTP adalah senyawa yang sengaja ditambahkan ke dalam makanan dalam jumlah dan ukuran tertentu dan terlibat dalam proses pengolahan, pengemasan, atau penyimpanan. Bahan ini berfungsi untuk memperbaiki warna, bentuk, cita rasa, dan tekstur, serta memperpanjang masa simpan, dan bukan merupakan bahan utama. Ironisnya, banyak pedagang yang menggunakan BTP yang berbahaya seperti formalin, boraks, pewarna dan pemutih yang justru dapat mengganggu kesehatan manusia Anak-anak merupakan merupakan salah satu sasaran makanan-makanan berbahaya yang sengaja diproduksi oleh oknum tertentu karena masih kurangnya pengetahuan tentang jenis bahan tambahan makanan. Tujuan kegiatan ini adalah untuk memperkenalkan tentang bahan tambahan makanan kepada anak-anak sejak dini sehingga ke depan memperhatikan dan selektif dalam mengkonsumsi jenis makanan tertentu. Metode yang digunakan bersifat penyuluhan dan disertai demonstrasi uji bahan berbahaya pada makanan.
\end{abstract}

Kata Kunci: bahan,tambahan,makanan,siswa 


\section{PENDAHULUAN}

Budaya jajan menjadi bagian dari keseharian hampir semua kelompok usia dan kelas sosial, termasuk anak usia sekolah dan golongan remaja (Titi S, 2004 dalam Qonita, 2010). Hampir semua anak usia sekolah suka jajan $(91,1 \%)$, selain nilai gizi makanan jajanan yang relatif rendah, keamanan pangan makanan jajanan juga menjadi masalah. Hasil penelitian Yayasan Lembaga Konsumen Indonesia (YLKI) menyimpulkan bahwa persentase makanan jajanan anak Sekolah Dasar (SD) yang dicampur dengan berbagai zat berbahaya masih sangat tinggi. Sebagai salah satu alternatif makanan bagi anak sekolah, nilai gizi dan nilai keamanan maka makanan jajanan masih perlu mendapat perhatian (Muhilal dkk, 2006 dalam Qonita, 2010). Penyakit yang diderita oleh anak SD terkait perilaku jajanan tidak sehat diantaranya cacingan $40-60 \%$, anemia $23,2 \%$, karies dan periodontal $74,4 \%$. Akibat perilaku yang tidak sehat ini dapat pula menimbulkan persoalan yang lebih serius seperti ancaman penyakit menular pada anak usia sekolah karena sekolah merupakan lokasi sumber penularan penyakit infeksi pada anak (Depkes, 20017).

Penelitian lain yang dilakukan oleh BPOM (2016) di daerah Jakarta
Timur mengungkapkan bahwa jenis jajanan yang sering dikonsumsi oleh anak-anak sekolah adalah lontong, otakotak, tahu goreng, mie bakso dengan saus, ketan uli, es sirop, dan cilok. Berdasarkan uji lab, pada otak-otak dan bakso ditemukan borax, tahu goreng dan mie kuning basah ditemukan formalin, dan es sirop merah positif mengandung rhodamin B. Bahan-bahan ini dapat terakumulasi pada tubuh manusia dan bersifat karsinogenik yang dalam jangka panjang menyebabkan penyakitpenyakit seperti kanker dan tumor pada organ tubuh manusia. Kandungan gizi dari makanan jajanan diatas seperti cilok terdiri dari kadar karbohidrat yang tinggi sedangkan proteinnya rendah, mie bakso terdiri dari lemak (2.51\%), protein $(5,78 \%)$, karbohidrat $(39,30 \%)$ dan kandungan tambahan lainnya seperti air (50,13\%). Mengkonsumsi cilok dan mie bakso dapat menambah kebutuhan protein, lemak dan karbohidrat, tapi tanpa bahan tambahan pangan berbahaya yang tidak baik bagi tubuh (Anita, 2006).

SD Santa Maria II Pekanbaru memiliki lokasi yang strategis berada di anatra dua jalan yang besar dan ramai yaitu Jalan Sukarno Hatta dan Jalan Durian. Lokasi yang padat penduduk ini 
menyebabkan banyaknya pedangpedagang makanan di area sekitar.

\section{METODE PELAKSANAAN}

Tahap pertama kegiatan ini adalah tahap perencanaan kegiatan yang akan dilakukan. Proses perencanaan awal mencakup identifikasi kebutuhan, penentuan jalan keluar dan kegiatan yang dilakukan, serta menyusun pengorganisasian kegiatan. Pada tahap awal kegiatan, tim pengabdi berkunjung ke SD Santa Maria 2 dan mengadakan pertemuan dengan Kepala Sekolah. Pada pertemuan awal ini tim pengabdian melakukan wawancara untuk mengidentifikasi kebutuhan. Dari kegiatan diskusi ini disepakati salah satu kegiatan yang dapat dilakukan di SD Santa Maria adalahpenyuluhan tentang bahan tambahan makanan bagi siswa SD kelas 4,5 dan 6.

Tahap kedua dari kegiatan ini adalah tahap persiapan materi, bahan dan perlengkapan seperti spanduk, kelengkapan administrasi yang diperlukan untuk kegiatan pengabdian. Sampel jajanan makanan disipakan bersama reagen dan test kit untuk pemeriksaan bahan bebahaya rhodamin $\mathrm{B}$, formalin dan boraks.

Tahap ketiga dari kegiatan ini adalah tahap pelaksanaan kegiatan pengabdian berupa penyuluhan tentang bahan tambahan makanan bagi siswa sekolah dasar. Dalam kegiatan ini juga dilakukan demonstrasi pemeriksaan bahan berbahaya rhodamin $\mathrm{B}$, formalin dan boraks pada sampel jajanan.

\section{HASIL DAN PEMBAHASAN}

Kegiatan penyuluhan ini dikuti oleh 56 siswa dan 6 orang guru pendamping. Seluruh peserta penyuluhan belum pernah mendapatkan sosialisasi tentang bahaya bahan tambahan pada makanan baik di kelas maupun diluar kelas. Hal ini tentu saja menjadi pengalaman baru yang penting bagi peserta. Dengan meningkatnya pengetahuan tentang bahaya bahan tambahan pada makan sehingga menjadi lebih selesktif dalam memilih makanan yang dikonsumsi terutama makanan jajanan.

Kegiatan penyuluhan dan demonstrasi pemeriksaan bahan berbahaya pada makanan dilakukan kurang lebih selama 3 jam. Diakhir pelaksanaan pengabdian siswa dan guru memberikan evaluasi dengan cara mengisi angket yang terdiri dari 5 pertanyaan dengan pilihan: Sangat Baik; Baik; Cukup dan Kurang. Hasil olah angket diperoleh data dengan rata - rata skor dinilai sangat baik. Selain itu terdapat usul saran dari pihak sekolah yang meminta kegiatan penyuluhan ini 
dilakukan secara kontinyu dengan topik

kesehatan lainnya.

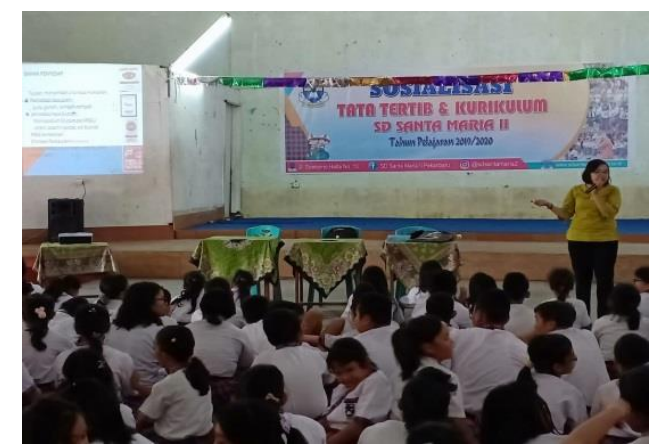

Gambar 1. Memberikan penyuluhan tentang bahan berbahaya pada zat tambahan makanan.

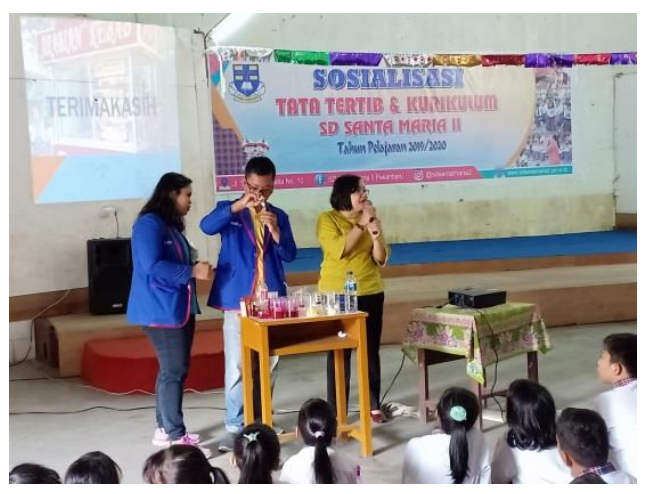

Gambar 2. Demonstrasi pemeriksaan kandungan bahan berbahaya beberapa sampel jajanan

\section{SIMPULAN}

Berdasarkan hal tersebut dapat disimpulkan bahwa kegiatan pengabdian kepada masyarakat oleh Akademi Kesehatan John Paul II telah memberikan kontribusi yang bermanfaat bagi siswa dan guru SD II Santa Maria pada khususnya dan berkontribusi dalam pengembangan pendidikan pada umumnya.

\section{DAFTAR RUJUKAN}

Anita. 2006. Analisis keamanan pangan jajanan dan upaya peningkatan mutunya. Skripsi. Fakultas Teknologi Pertanian Institut Pertanian Bogor.

BPOM. 2016. Upaya badan POM dalam upaya menghadapi tantangan keamanan pangan jajanan anak sekolah. Jakarta

Depkes RI. 2017. Aspek Gizi Makanan Jajanan. Jakarta. Direktorat Jenderal Pembinaan Kesehatan Masyarakat

Qonita, N. 2010. Hubungan kontribusi energi dan protein dari makanan jajanan dengan status gizi anak SDN 30 Labui Banda Aceh. www.scribd.com/nita_qonita. ( akses tanggal 28 Maret 2019 jam 12.56) 